\title{
Inhibition of Humoral and Cell-Mediated Immune Responses in Man by Distinct Suppressor Cell Systems
}

\author{
Peter I. Lobo and Clinton E. Spencer, Renal Immunology Division, Department \\ of Internal Medicine, University of Virginia Medical Center, \\ Charlottesville, Virginia 22908
}

\begin{abstract}
A B S T RACT Studies were designed to investigate whether the suppressor cell systems that regulate the humoral and cell-mediated immune responses belong to the same subsets of $\mathrm{T}$ cells or different subsets. Mitogen-activated suppressor cells were simultaneously assayed for their ability to inhibit $(a)$ pokeweed mitogeninduced generation of plasma cells, $(b)$ blastogenic response of lymphocytes to allogeneic cells, and $(c)$ generation of killer cells in the cell-mediated lymphocytotoxicity assay. We found that suppressor cells that inhibited the generation of plasma cells were activated by concanavalin $\mathrm{A}$ (Con $\mathrm{A}$ ) and were both radiation and prednisone sensitive. Suppressors that inhibited the blastogenic response in lymphocytes to allogenic cells were also activated by Con A but differed in that they were both radiation and prednisone resistant. In contrast, suppressors that inhibited the generation of the killer cells were activated with phytohemagglutinin and not Con A. These suppressors were prednisone and radiation resistant. These observations cannot be explained by differences at the pro-suppressor or suppressor activator levels as both $\mathrm{T}$ cell subsets are radiosensitive. Alternatively, heterogeneity of suppressor cell systems may explain these differences.
\end{abstract}

\section{INTRODUCTION}

Lymphocytes with suppressor and helper activity are now recognized to be important in the regulation of humoral and cell-mediated immune responses $(1,2)$. Considerable evidence has now emerged to indicate that stimulatory and inhibitory influences are mediated by different cells and not the same cells (3-5). More recently, it has been demonstrated that interaction between different subsets of $T$ cells and non- $T$ cells are required to generate suppressor activity $(5-7)$. In the present paper we present evidence to indicate that the suppressor cell systems (i.e., the complex of interact-

Received for publication 28 August 1978 and in revised form 26 January 1979. ing $T$ cells, non- $T$ cells, and macrophages) that regulate humoral and cell-mediated immune systems are distinct. In these studies, suppressor cells were activated by mitogens, which nonspecifically suppress both humoral and cell-mediated immune responses $(8,9)$.

\section{METHODS}

Isolation of lymphocytes. Lymphocytes were separated from fresh heparinized blood ( $50 \mathrm{U}$ beef heparin $/ \mathrm{ml}$ blood) from healthy, volunteer adult donors by Ficoll-Hypaque density gradient centrifugation (Ficoll, Pharmacia Fine Chemicals Inc., Piscataway, N. J.; Hypaque, Winthrop Laboratories, New York) and then finally resuspended in RPMI 1640 (Grand Island Biological Co., Grand Island, N. Y.) containing $20 \%$ heat-inactivated human AB serum, $80 \mu \mathrm{m} / \mathrm{ml}$ glutamine, 50 $\mu \mathrm{g} / \mathrm{ml}$ streptomycin, and $50 \mu \mathrm{g} / \mathrm{ml}$ penicillin (RPMI culture medium).

Generation of suppressor cells by mitogen stimulation. Previously described techniques were used $(10,11)$. Aliquots of $3 \times 10^{6}$ cells suspended in $1 \mathrm{ml}$ of RPMI were incubated for $48 \mathrm{~h}$ at $37^{\circ} \mathrm{C}$ in Falcon plastic tubes $(12 \times 75 \mathrm{~mm}$; Falcon Labware, Div. of Becton, Dickinson \& Co., Oxnard, Calif.). These "precultures" were performed either in culture medium alone (control) or in the presence of $32 \mu \mathrm{g} / \mathrm{ml}$ concanavalin A (Con A, ${ }^{1}$ grade III, lot 16C-7210, Sigma Chemical Co., St. Louis, Mo.) or $0.1 \mathrm{ml}$ phytohemagglutinin P (PHA; lot 626708, 1:15 dilution of stock solution, Difco Laboratories, Detroit, Mich.). After $48 \mathrm{~h}$, precultures were paralyzed with mitomycin C $\left(25 \mu \mathrm{g} / \mathrm{ml}\right.$, during $20 \mathrm{~min}$ at $37^{\circ} \mathrm{C}$, ICN Nutritional Biochemicals, Cleveland, Ohio), washed four times with RPMI, and made up to a final concentration of $2 \times 10^{6}$ cells $/ \mathrm{ml}$ before use in the various assay systems to quantitate suppressor cell activity. In certain experiments, cells were exposed to methylprednisolone (10 $\mu \mathrm{g} / \mathrm{ml}$, Upjohn Co., Kalamazoo, Mich.) or radiation $(2,000 \mathrm{rad})$ just before adding the mitogen. The methylprednisolone was present throughout the preculture period.

Pokeweed mitogen (PWM)-induced production of intracytoplasmic immunoglobulin (Ig). In this assay, freshly prepared cells in RPMI $\left(2 \times 10^{6}\right.$ cells) were incubated with PWM (Grand Island Biological Co., lot C477101) to achieve a final concentration of $1: 100$ of the stock solution of

${ }^{1}$ Abbreviations used in this paper: CML, cell-mediated lymphocytotoxicity; Con A, concanavalin A; MLC, mixed lymphocyte culture; PHA, phytohemagglutinin; PWM, pokeweed mitogen. 
mitogen. PWM-treated cells were cultured for $8 \mathrm{~d}\left(5 \% \mathrm{CO}_{2}\right.$, $37^{\circ} \mathrm{C}$ ) in Falcon plastic tubes and production of intracytoplasmic immunoglobulin was determined by making cytocentrifuge preparations of cells as described (12) and staining these preparations with goat antiserum to human Ig (polyvalent, Hyland Diagnostics Div., Travenol Laboratories, Inc., Costa Mesa, Calif.). Between 2,000 and 3,000 cells were counted to determine the percentage of cells with intracytoplasmic Ig.

One-way mixed lymphocyte culture (MLC). $0.05 \mathrm{ml}$ of freshly prepared responder cells $\left(2 \times 10^{6} / \mathrm{ml}\right)$ in RPMI were mixed with an equal volume of freshly prepared mitomycin paralyzed allogeneic stimulator in microculture plates. The cultures were incubated for $6 \mathrm{~d}\left(5 \% \mathrm{CO}_{2}, 37^{\circ} \mathrm{C}\right)$ and $\left[{ }^{3} \mathrm{H}\right]$ thymidine uptake (blastogenic response) was determined after adding $2 \mu \mathrm{l}$ of the isotope to each well for the last $18 \mathrm{~h}$ of incubation.

Cell-mediated lymphocytotoxicity (CML). In vitro generation of killer cells was achieved by described techniques (13). Briefly, MLC cultures in Falcon plastic tubes that contained $1 \mathrm{ml}$ each of freshly prepared responder and stimulator cells $\left(1.5 \times 10^{6} \mathrm{cell} / \mathrm{s} / \mathrm{ml}\right)$ were incubated for $8 \mathrm{~d}$. Development of cytotoxicity activity (CML) was quantitated by incubating washed cultured cells (in $0.15 \mathrm{ml}$ RPMI) for $5 \mathrm{~h}$ with ${ }^{51} \mathrm{Cr}$ labeled target cells ( $1.5 \times 10^{4}$ cells in $0.15 \mathrm{ml}$ RPMI), obtained from the same donor as the stimulator cells in the MLC. In this assay, macrophage-depleted target cells were preincubated with PHA $(0.1 \mathrm{ml}$ of 1:120 dilution of stock solution of PHA to $1 \mathrm{ml}$ of cells that contained $3-5 \times 10^{6}$ cells) for $48 \mathrm{~h}$ before labeling with ${ }^{51} \mathrm{Cr}$ for use in the $\mathrm{CML}$ assay. The degree of target cell destruction was obtained by the following equation: percentage of cytotoxicity $=($ experimental - spontaneous release $\times 100) /($ freeze-thaw - spontaneous release, where spontaneous release equals release of ${ }^{51} \mathrm{Cr}$ from target cells when left in RPMI and freeze-thaw release equals maximum release determined by rapidly freeze-thawing target cells three times in liquid nitrogen.

Basic experimental design to determine mitogen-induced suppressor cell activity. Aliquots of control (cells precultured in RPMI without mitogens) and mitogen-activated suppressor cells were added at the initiation (day 0) of the various assay systems, which are (a) PWM-induced intracytoplasmic Ig, (b) MLC, and (c) CML. The number of precultured cells added was the same as the number of responder cells in these assay systems. Mitogen-activated suppressor cells were obtained from the same donor as the responder cells in these assays (autologous suppression). The degree of suppression or enhancement was determined by the following equation: percentage of inhibition (or enhancement) $=$ (response with MS - response with $C S \times 100) /$ response with CS, where MS represents mitogen-activated suppressor cells and CS represents cells cultured in RPMI without mitogens. A greater than $20.0 \%$ inhibition was regarded as suppression in these experiments.

Preparation of enriched non- $T$ target cells. Isolated lymphocytes were subjected to rosette formation with unsensitized sheep erythrocytes by published techniques (14). After overnight incubation at $4^{\circ} \mathrm{C}$, the rosette suspension was Ficoll-Hypaqued at $4^{\circ} \mathrm{C}$. Cells at the interface were washed three times in RPMI and utilized as non-T cells. Such preparations had $>50 \%$ IgM staining lymphocytes and were kept in culture at $37^{\circ} \mathrm{C}$ for $72 \mathrm{~h}$ before being labeled with ${ }^{51} \mathrm{Cr}$ and utilized as targets in cytotoxicity assays.

Removal of macrophages from mononuclear cell suspensions. Isolated mononuclear cell suspensions in RPMI with $10 \%$ fetal calf serum were incubated in plastic dishes at $37^{\circ} \mathrm{C}$ for $45 \mathrm{~min}$. Nonadherent cells were gently washed off these dishes and re-incubated a second time in similar dishes before such nonadherent cell suspensions were used in macrophage- depleted experiments. With this procedure, the percentage of contaminated macrophages, identified by ingestion of latex particles or eucrysine staining of lysozymes was reduced from a mean of $18 \%$ (range $12-32 \%$ ) to $<3 \%$.

\section{RESULTS}

Effect of Con A-precultured lymphocytes on PWMinduced intracytoplasmic Ig. As shown in Table I, autologous Con A-precultured lymphocytes inhibited the production of intracytoplasmic Ig by lymphocytes. This inhibitory effect was abolished when lymphocytes, before activation with Con $\mathrm{A}$, were pretreated with methylprednisolone or radiation, indicating that the suppressor cell system inhibiting Ig production was sensitive to prednisone and radiation. Sensitivity to prednisone and radiation was detectable (i.e., $50 \%$ loss of activity) at $2.0 \mu \mathrm{g}$ and $600 \mathrm{rad}$, respectively.

Previous investigators have demonstrated that Con A-induced suppressors of Ig synthesis are inactivated by mitomycin $\mathrm{C}$ treatment (7). Because our data are contrary to published reports, we repeated these studies with $(a)$ Con A-induced suppressors that were not paralyzed with mitomycin C, $(b)$ Con A-induced suppressors that were paralyzed with mitomycin $C$ at the onset of the precultured period, and $(c)$ Con A-induced suppressors that were paralyzed after the $48 \mathrm{~h}$ preculture. Representative data from two of the nine subjects are depicted in Table II. Our studies indicate that in the absence of mitomycin C, Con A-induced suppressors inhibited Ig synthesis by $82.4 \pm 8.9 \mathrm{SD}$, whereas the same suppressors, after mitomycin $C$ paralysis, inhibited Ig synthesis by 45.0 \pm 13.1 SD. Additionally, it is apparent that substantial suppressor activity can be generated despite lack of cell division. Paralysis of cells with mitomycin before the addition of Con A, generated similar degree of suppressor activity as paralysis after $48 \mathrm{~h}$. The discrepancy between our results and that reported by others (7) cannot be explained by incomplete paralysis of mitosis of Con A-precultured cells. Cells pretreated with Con A for $48 \mathrm{~h}$ were paralyzed with mitomycin $\mathrm{C}$ and then left in culture for an additional 2-5 d. Mean $\left[{ }^{3} \mathrm{H}\right]$ thymidine uptake in six such experiments was $238 \pm 42 \mathrm{SD}$ and not different from controls similarly pretreated but not exposed to mitogen.

Effect of Con A-precultured lymphocytes on blastogenic transformation of lymphocytes towards allogenic lymphocytes $(M L C)$. These studies were performed in parallel on lymphocytes obtained from the same donors (and on the same day) used to evaluate inhibition of intracytoplasmic Ig. As evident from Table I, autologous Con A-precultured lymphocytes also inhibited the blastogenic response in the MLC assay. However, in contrast to the inhibition of intracytoplasmic Ig production by Con A-precultured lymphocytes, the suppressor cell system inhibiting blastogenesis was re- 
TABLE I

Effects of Prednisone and Radiation on the Generation of Con A-Activated Suppressor Cells that Inhibit PWM-Induced Intracytoplasmic Ig and Blastogenic Response of Normal Human Lymphocytes to Allogenic Cells (MLC)

\begin{tabular}{|c|c|c|c|c|c|}
\hline \multirow[b]{2}{*}{$\begin{array}{l}\text { Sub- } \\
\text { jects }\end{array}$} & \multirow[b]{2}{*}{$\begin{array}{l}\text { Precultured } \\
\text { cells* }\end{array}$} & \multicolumn{2}{|c|}{$\begin{array}{c}\text { PWM-induced } \\
\text { intracytoplasmic Igt }\end{array}$} & \multicolumn{2}{|c|}{$\begin{array}{l}\text { Blastogenic response } \\
\text { in MLC assay }\end{array}$} \\
\hline & & $\begin{array}{c}\text { Ig- } \\
\text { positive } \\
\text { cells }\end{array}$ & $\begin{array}{c}\text { Inhibi- } \\
\text { tion§ }\end{array}$ & $\begin{array}{c}{\left[{ }^{3} \mathrm{H}\right]} \\
\text { Thymidine } \\
\text { uptake }\end{array}$ & $\begin{array}{c}\text { Inhibi- } \\
\text { tion§ }\end{array}$ \\
\hline & & $\%$ & $\%$ & $c p m$ & $\%$ \\
\hline \multirow[t]{4}{*}{ M.S. } & Control" & 5.7 & & 45,718 & \\
\hline & Con A & 3.1 & -45.6 & 27,260 & -40.4 \\
\hline & Con $\mathrm{A}+\mathrm{MP}$ & 9.1 & +59.7 & 30,994 & -32.2 \\
\hline & Con $\mathrm{A}+\mathrm{rad}$ & 4.6 & -19.3 & 25,179 & -44.9 \\
\hline \multirow[t]{4}{*}{ P.L. } & Control & 6.7 & & 89,783 & \\
\hline & Con A & 2.0 & -70.1 & 38,686 & -56.9 \\
\hline & Con $\mathrm{A}+\mathrm{MP}$ & 6.0 & -10.4 & 34,766 & -61.3 \\
\hline & Con $A+\operatorname{rad}$ & 8.8 & +31.3 & 33,671 & -62.5 \\
\hline \multirow[t]{4}{*}{ C.S. } & Control & 1.4 & & 23,724 & \\
\hline & Con A & 0.6 & -57.1 & 9,390 & -60.4 \\
\hline & Con $\mathrm{A}+\mathrm{MP}$ & 1.9 & +35 & 10,771 & -54.6 \\
\hline & Con $\mathrm{A}+\mathrm{rad}$ & 2.2 & +57.1 & 10,086 & -57.5 \\
\hline \multirow[t]{4}{*}{ R.K. } & Control & 6.2 & & 92,852 & \\
\hline & Con A & 2.2 & -64.5 & 51,685 & -44.3 \\
\hline & Con $\mathrm{A}+\mathrm{M}$ & 7.3 & +17.7 & 41,017 & -55.8 \\
\hline & Con $A+\operatorname{rad}$ & 7.0 & +12.9 & 55,891 & -39.8 \\
\hline
\end{tabular}

* Cells were incubated in RPMI without (control) or with Con A $(32 \mu \mathrm{g} / \mathrm{ml})$ for $48 \mathrm{~h}$. Cells were then treated with mitomycin C $(25 \mu \mathrm{g} / \mathrm{ml})$ for $20 \mathrm{~min}$, washed four times before adding to freshly prepared autologous responder lymphocytes. The latter were either stimulated with PWM or with freshly prepared mitomycin C-paralyzed allogeneic cells (MLC assay). The number of precultured cells added was equal to the number of responder cells. In certain experiments, both control and Con A-pretreated cells were subjected to methylprednisolone (MP, $10 \mu \mathrm{g} / \mathrm{ml}$ ) or radiation $(2,000 \mathrm{rad})$ at initiation of these precultures. Cultures were performed in quadruplicate and values represent a mean.

\ PWM-stimulated cells were kept in culture for $8 \mathrm{~d}$, washed, and cytocentrifuge preparations of these cells were examined for intracytoplasmic Ig. 2,000-3,000 cells were counted to determine the percentage of Ig-positive cells.

$\$$ Percentage of inhibition $(-)$ or enhancement $(+)$ equals response with mitogen-pretreated cells minus response with control pretreated cells divided by response with control pretreated cells $\times 100$.

" Data on control precultures subjected to MP or radiation are not included in this table as no differences were noted. However, values for controls + MP or radiation were used in calculations for percentage of inhibition after Con $A,+M P$, or radiation.

sistent to the effects of methyprednisolone $(10.0 \mu \mathrm{g})$ or radiation (2,000 $\mathrm{rad})$.

Because suppression of MLC responses with Con A-precultured cells could result from excess Con A
TABLE II

Effect of Paralysis of Cell Division by Mitomycin C on the Generation of Con A-Induced Suppressors of Ig Synthesis

\begin{tabular}{|c|c|c|c|c|c|}
\hline \multirow[b]{2}{*}{$\begin{array}{c}\text { Pre- } \\
\text { cultures }\end{array}$} & \multirow[b]{2}{*}{$\begin{array}{c}\text { Mitomycin C } \\
\text { paralysis* }\end{array}$} & \multicolumn{2}{|c|}{ Subject P.L. } & \multicolumn{2}{|c|}{ Subject R.K. } \\
\hline & & $\underset{\text { positive }}{\text { Ig }}$ & Inhibition & $\begin{array}{c}\mathrm{Ig} \\
\text { positive }\end{array}$ & Inhibition \\
\hline & & & 6 & & $\%$ \\
\hline Control & None & 7.8 & & 8.6 & \\
\hline Con A & None & 2.2 & -72.0 & 0.8 & -90.6 \\
\hline Control & At onset & 6.9 & & 8.0 & \\
\hline Con A & At onset & 3.8 & -44.9 & 3.6 & -55.0 \\
\hline Control & After $48 \mathrm{~h}$ & 6.6 & & 8.4 & \\
\hline Con A & After $48 \mathrm{~h}$ & 3.9 & -40.9 & 3.6 & -57.1 \\
\hline
\end{tabular}

* Cells were paralyzed with mitomycin C $(25 \mu \mathrm{g} / \mathrm{ml}$ during $20 \mathrm{~min}$ at $37^{\circ} \mathrm{C}$ ) either at the onset of the precultures or after the cells were precultured for $48 \mathrm{~h}$.

bound to cell membranes (rather than through activation of suppressive influences), we examined this possibility by incubating pretreated controls with Con A for $1 \mathrm{~h}$. Experiments from nine subjects revealed a mean suppression of $2.0 \pm 1.0 \% \mathrm{SD}$.

Effect of Con A- and PHA-precultured lymphocytes on the in vitro generation of killer lymphocytes $(C M L)$. Because of the marked suppressive effects of Con A-precultured lymphocytes on the blastogenic transformation of lymphocytes in response to allogenic lymphocytes, studies were conducted to determine if the in vitro generation of killer lymphocytes were similarly inhibited. Autologous Con A-precultured lymphocytes were, therefore, simultaneously added at the initiation of either MLC or CML cultures. The data in Table III demonstrate that Con A-precultured lymphocytes, despite being effective suppressors of the MLC assay (Table I), did not inhibit the generation of killer lymphocytes. Because of previous reports indicating that the mitogen PHA can also activate suppressor lymphocytes, we performed similar studies with PHAprecultured lymphocytes (15). As is evident in Table III, PHA-precultured lymphocytes inhibited the generation of killer lymphocytes. In two subjects, CML responses were measured on days $6,7,8$, and 9 to determine if the observed suppression of CML responses on day 8 merely reflected a kinetic shift in the CML response to an earlier time point. Data on these two subjects indicated that PHA-precultured lymphocytes did not shift the CML response to an earlier time point despite enhanced blastogenesis. Continued suppression of CML response was observed from days 6 to 9. Suppressor cells capable of suppressing the generation of killer lymphocytes were, however, resistent to the effects of the prednisone and radiation.

Studies to determine the mechanism of suppression 
TABLE III

Preculturing Autologous Cells with either Con A or PHA to Determine if They Will Develop into Suppressor Cells that can Alter the In Vitro Generation of Cytotoxic T Lymphocytes (CML)

\begin{tabular}{lllr}
\hline & & \multicolumn{2}{c}{ CML assayt } \\
\cline { 3 - 4 } Subjects & $\begin{array}{c}\text { Precultured } \\
\text { cells }\end{array}$ & Cytotoxicity $\S$ & Inhibition \\
\hline & & \multicolumn{2}{c}{$\%$} \\
L.M. & Control & 42.3 & \\
& Con A & 46 & +8.7 \\
& PHA & 12 & -71.6 \\
C.S. & Control & 84.6 & \\
& Con A & 76.9 & -9.1 \\
& PHA & 65 & -23.2 \\
P.L. & Control & 84.6 & \\
& Con A & 78.2 & -7.5 \\
& PHA & 30.7 & -63.7 \\
J.G. & Control & 55.7 & \\
& Con A & 53.4 & -4.1 \\
& PHA & 9.8 & -82.4 \\
\hline
\end{tabular}

* Same as in Table I.

† In vitro generation of killer $\mathrm{T}$ cells for the CML assay was achieved by culturing $1 \mathrm{ml}$ of freshly prepared responder and $1 \mathrm{ml}$ of mitomycin C-paralyzed stimulator cells $\left(1.5 \times 10^{6}\right.$ cells $/ \mathrm{ml}$ ) for $8 \mathrm{~d}$. Cytotoxicity was determined by washing (4 times) the 8-d cultured cells and then incubating these cells with ${ }^{51} \mathrm{Cr}$-labeled target cells $\left(1.5 \times 10^{4}\right.$ cells $)$ autologous to the stimulator cells. Target cells were preincubated with PHA for $48 \mathrm{~h}$ before labeling with ${ }^{51} \mathrm{Cr}$. Precultured cells were added at the initiation of cultures (day 0 ) to inhibit the generation of killer $\mathbf{T}$ cells.

$\$$ The equation for determining percentage of cytotoxicity is described in Methods.

by Con A- and PHA-precultured lymphocytes. Hunninglake and Fauci (16) have previously demonstrated that Con A pretreatment of cells can lead to the generation of autoreactive cytotoxic cells, which are particularly effective when an agglutinin is present in the cytotoxicity assay. These observations led us to investigate whether the observed suppression resulted from cytolysis of responder lymphocytes. Particular attention was directed to the suppression of intracytoplasmic Ig production especially because an agglutinin (PWM) was present in this assay system. This was evaluated by determining whether $48 \mathrm{~h}$ Con A-precultured lymphocytes were cytotoxic to non-T autologous cells, which are enriched for responders of Ig synthesis. In these experiments, mitomycin C-paralyzed, Con A-precultured lymphocytes were incubated with ${ }^{51} \mathrm{Cr}$-labeled non-T cells for periods of $4-16 \mathrm{~h}$ at $37^{\circ} \mathrm{C}$ in the presence of PWM. The data (Table IV) indicate that mitogen-precultured lymphocytes do not lead to cytoly-
TABLE IV

Experiments to Determine if Mitogen-Activated Precultured Cells were Cytotoxic to Autologous Non-T Cells and Allogeneic Cells

\begin{tabular}{|c|c|c|c|c|c|}
\hline \multirow[b]{3}{*}{ Subjects } & \multirow{3}{*}{$\begin{array}{l}\text { Precultured } \\
\text { cells }\end{array}$} & \multicolumn{4}{|c|}{${ }^{51} \mathrm{Cr}$ targets* } \\
\hline & & \multicolumn{2}{|c|}{$\begin{array}{l}\text { Autologous } \\
\text { non-T cells }\end{array}$} & \multicolumn{2}{|c|}{$\begin{array}{l}\text { Allogeneic } \$ \\
\text { cells }\end{array}$} \\
\hline & & $20: 1^{11}$ & $60: 1$ & 20:1 & $60: 1$ \\
\hline & & & & cicity & \\
\hline \multirow[t]{3}{*}{ P.L. } & Control & - & - & - & - \\
\hline & PHA & -1 & +6.0 & 0 & +9.4 \\
\hline & Con A & 0 & +7.2 & +0.5 & +11.1 \\
\hline \multirow[t]{3}{*}{ J.G. } & Control & - & - & - & - \\
\hline & PHA & 0 & +7.8 & -0.5 & +11.1 \\
\hline & Con A & -1.5 & +7.5 & +1.0 & +9.8 \\
\hline \multirow[t]{3}{*}{ R.K. } & Control & - & - & - & - \\
\hline & PHA & +0.5 & +5.1 & 0 & +13.3 \\
\hline & Con A & -0.5 & +4.9 & -1.5 & +11.5 \\
\hline
\end{tabular}

${ }^{*}$ The figures are the difference in percentage of ${ }^{51} \mathrm{Cr}$ release from those cultures that contained control precultured cells. ${ }^{51} \mathrm{Cr}$ release at $4 \mathrm{~h}$ was calculated with the following equation: percentage of ${ }^{51} \mathrm{Cr}$ release $=$ counts per minute in supernate $\times 100$ /counts per minute in supernate + counts per minute in pellet. Background isotope release varied from 15 to $22 \%$ and maximum isotope release (freeze-thaw) varied from 71 to $85 \%$. \$ Non-T target cells were obtained and prepared as described in Methods. PWM was present in this cytotoxicity assay. $5 \times 10^{4}{ }^{51} \mathrm{Cr}$-labeled non- $\mathrm{T}$ targets were incubated with varying numbers of effectors as indicated.

$\$$ Allogeneic targets were mononuclear cells that were kept in culture at $37^{\circ} \mathrm{C}$ for $72 \mathrm{~h}$ before being used as targets. The number and proportions of effector to target cells were the same as those used in the non-T cell experiments.

" Effector to target cell ratio. Effector cells were pretreated in RPMI that contained pooled heat-inactivated AB serum and in the presence or absence of mitogen.

sis of these responder cells even when PWM is present in the cytotoxicity assay provided the effector to target cell ratio was $<20: 1$.

The same investigators have also demonstrated that mitogen pretreatment of cells can lead to the generation of cells that are cytotoxic to allogeneic cells. These observations prompted us to investigate whether the PHA-precultured lymphocytes inhibited the in vitro generation of killer lymphocytes (CML assay) by cytolysis of the stimulator cell during the initial MLC. Accordingly, mytomycin C-paralyzed, PHA-precultured lymphocytes were incubated with ${ }^{51} \mathrm{Cr}$-labeled allogeneic cells. The results (Table IV) again indicate that mitogen-precultured lymphocytes, when used at an effector to target cell ratio of 20:1, do not lead to cytolysis of allogeneic cells. 
Studies to determine if the differential effects of prednisone and irradiation are dependent on macrophages. Studies were performed $(a)$ to determine the requirement of macrophages in mitogen-activated suppressors of both the humoral and cell-mediated immune responses and $(b)$ to determine if the differential effects of prednisone and irradiation on the various mitogenactivated suppressors were dependent on macrophages. Mononuclear cell suspensions depleted of macrophages by plating were used in these studies. Experiments determining suppressor activity simultaneously in all three assay systems demonstrated that mitogenactivated suppressors of Ig synthesis and killer cell activation did not require macrophages. However, variable results were obtained for mitogen-activated suppressor of alloantigen-stimulated blast transformation (MLC). In two of the five subjects studied, no diminution of suppressor cell activity was observed in macrophage-depleted, Con A-activated suppressors. However, in the remaining three, suppressor activity was reduced by half in macrophage-depleted preparations. Representative examples are presented in Table V. Of importance, removal of macrophages did not alter the pattern of sensitivity to prednisone and radiation of the various mitogen-activated suppressors (Table V), demonstrating that the differential effects observed with prednisone and irradiation is at a nonmacrophage level.

\section{DISCUSSION}

The data presented indicate that suppressor cell systems are heterogenous. Suppressors regulating Ig production were activated by Con $A$ and were rendered ineffectual with prednisone or irradiation. This is in keeping with previous observation in humans $(17,18)$. In contrast, suppressors inhibiting proliferative responses were resistant to both prednisone and radiation. Finally, suppressors that modulated the generation of killer cells differed from the previous two suppressor systems in that Con A, in the doses used, failed to activate them. Instead, they were activated by PHA. These suppressors were, however, resistant to both prednisone and radiation.

These results demonstrating differences in the various suppressor cell systems cannot be accounted for by differences in donors, preculturing techniques, and nonspecific allotype suppression. Variations from such causes were reduced by $(a)$ utilizing autologous assay cell systems, i.e., precultured mitogen-activated cells were autologous to the responder cells, $(b)$ performing the various assay system in parallel, and $(c)$ dividing the precultured cells after mitomycin paralysis into aliquots for the various assay systems. Additionally, precultured cells were washed four times before ad-
TABLE V

Effect of Prednisone and Irradiation on Con A-Activated Suppressors Depleted of Macrophages

\begin{tabular}{|c|c|c|c|c|c|}
\hline \multirow[b]{2}{*}{$\begin{array}{l}\text { Sub- } \\
\text { jects }\end{array}$} & \multirow[b]{2}{*}{$\begin{array}{l}\text { Precultured } \\
\text { cells }\end{array}$} & \multicolumn{2}{|c|}{$\begin{array}{l}\text { Blastogenic response } \\
\text { in MLC assay }\end{array}$} & \multicolumn{2}{|c|}{$\begin{array}{c}\text { PWM-induced } \\
\text { intracytoplasmic Ig }\end{array}$} \\
\hline & & $\begin{array}{l}\text { Macs* } \\
\text { present }\end{array}$ & $\begin{array}{c}\text { Macs } \\
\text { depleted }\end{array}$ & $\begin{array}{l}\text { Macs } \\
\text { present }\end{array}$ & $\begin{array}{l}\text { Macs } \\
\text { depleted }\end{array}$ \\
\hline & & \multicolumn{2}{|c|}{ \% inhibition } & \multicolumn{2}{|c|}{$\%$ inhibition $\ddagger$} \\
\hline P.L. & $\begin{array}{l}\text { Con A } \\
\text { Con A + MP } \\
\text { Con A + rad }\end{array}$ & $\begin{array}{l}-42.9 \\
-46.9 \\
-38.7\end{array}$ & $\begin{array}{l}-53.7 \\
-55.8 \\
-41.2\end{array}$ & $\begin{array}{l}-44.4 \\
+21.3 \\
+26.7\end{array}$ & $\begin{array}{l}-45.3 \\
+38.7 \\
+42.3\end{array}$ \\
\hline G.P. & $\begin{array}{l}\text { Con A } \\
\text { Con A + MP } \\
\text { Con A + rad }\end{array}$ & $\begin{array}{l}-49.5 \\
-54.3 \\
-56.7\end{array}$ & $\begin{array}{l}-28.8 \\
-24.5 \\
-27.3\end{array}$ & $\begin{array}{l}-40.2 \\
+22.7 \\
+37.3\end{array}$ & $\begin{array}{l}-77.7 \\
+44.4 \\
+27.3\end{array}$ \\
\hline C.S. & $\begin{array}{l}\text { Con A } \\
\text { Con A + MP } \\
\text { Con A + rad }\end{array}$ & $\begin{array}{l}-80.9 \\
-71.2 \\
-76.0\end{array}$ & $\begin{array}{l}-40.6 \\
-41.0 \\
-55.7\end{array}$ & $\begin{array}{l}-50.2 \\
+75.0 \\
+62.0\end{array}$ & $\begin{array}{l}-66.3 \\
+71.4 \\
+82.3\end{array}$ \\
\hline
\end{tabular}

* Macs, macrophages. Macrophages depleted preparations had $<3 \%$ macrophages.

† Same as in Table I.

dition to the assay systems. Hence, the possibility of mitogen or prednisone from the precultures affecting the responders becomes unlikely. Rather, a direct interaction between the precultured, activated suppressor and the responders has to be postulated.

It could be argued that the observed heterogeneity in suppressors may be accounted for by differences in mechanisms of suppression between the mitogen-activated, precultured cells and the various responder effector systems. Specifically, the mitogen-activated, precultured cells could give rise to a suppressive effect by (a) killing of the responders in one system (for example, with intracytoplasmic Ig) and (b) killing of the allogeneic stimulators in the other systems (for example, with the MLC or CML assays). With regard to the first possibility there is evidence to indicate that Con A pretreatment of cells can lead to the generation of autoreactive cytotoxic cells that are particularly effective when an agglutinin is present in the cytotoxic assay (16). Hence, suppression of intracytoplasmic Ig may be predominantly the result of cytolysis of the responder cells because of the presence of PWM in the assay system. In examining this possibility, we found no evidence of increased cell death in this assay system, thus also confirming previously made observations (19, 21). With regard to the second possibility, Hunninglake and Fauci (16) have demonstrated that mitogen-activated cells were highly cytotoxic for allogeneic target cells. Hence, suppression of the CML assay observed with the PHA-activated precultures could represent a direct cytotoxicity of such mitogen-activated cells 
towards the allogeneic stimulator cell in the CML or MLC assay. This possibility was untenable in our system because lysis of stimulator cells was observed by these investigators and also by us only when the ratio of mitogen-activated cells to target cells was $>20: 1$.

A more plausible explanation for the apparent heterogeneity is that suppression of humoral and cellular immune mechanisms may indeed be mediated by distinct suppressor cell systems. Previous investigators have convincingly demonstrated that mitogen-activated suppressors requires the interaction of $\mathrm{T}$-cell subsets (suppressor cell precursors and suppressor "amplifiers"), a non- $T$, non-B-cell subset, and macrophages (5-7). Our data would indicate that the heterogeneity of suppressor cell systems lies at the T-cell level mainly because of (a) persistence of the pattern of sensitivity to prednisone and irradiation of the various mitogen-activated suppressors despite macrophage depletion, $(b)$ requirement of different mitogens to activate the various suppressor cell systems (PHA but not Con A can activate suppressors of the CML assay), and (c) the studies of Broder et al. (5) demonstrating in humans that the suppressor cell precursors and suppressor amplifiers that regulate Ig production are both radiosensitive. Additional evidence in humans supporting the concept of heterogeneity at the T-cell level is data in the present studies and those of other investigators indicating that macrophages are not important to generate mitogenactivated suppressors that regulate Ig production (22) and that non-T cells are not required to generate Con A-activated suppressors that regulate the blastogenic response $(15,23)$. That regulatory populations may indeed derive from different $\mathrm{T}$-cell pools has also been suggested by others $(24,25)$. Tada et al. (24), in particular, have demonstrated in an antigen-activated helper cell system that distinct types of helper cells (Ly $1, \mathrm{Ia}-$ or Ly $1, \mathrm{Ia}+$ ) were activated depending on whether the hapten and carrier were in one molecule or separate.

A surprising observation was the presence of substantial suppressor activity of the Con A-induced suppressors of Ig synthesis despite mytomycin C paralysis. Our results agree to some extent with those of other investigators who demonstrate that mitomycin C inhibits the generation of Con A-induced suppressors of Ig synthesis, but our data are at variance in that this inhibition is not complete (7). Furthermore, the discrepancy between our results and that reported by these investigators, could not be explained by incomplete inhibition of blast transformation of Con Aactivated cells. Our results are, however, in keeping with those of others demonstrating that mitomycin $\mathrm{C}$ paralysis does not inhibit the generation of Con Ainduced suppressors of blastogenesis $(15,23)$. More studies, however, are needed in this area to resolve these conflicting reports.
Nonspecific activation of large numbers of suppressor cells with mitogens may be entirely different from the in vivo situation, which depends on antigen-specific suppressor cell activation. Perhaps the differences we observed may be purely artificial and not exist in vivo. However, the association of hypergammaglobulinemia with a reduction in cell-mediated immunity (e.g., in systemic lupus erythematosus and sarcoidosis) and the converse (e.g., in variable hypogammaglobulinemia) is difficult to explain purely on the basis of an imbalance of a single suppressor cell system. The observation by Stobo et al. (26) demonstrating that suppressor $\mathrm{T}$ cells from patients with disseminated fungal infections were able to suppress autologous cells from responding to mitogens but not synthesis of Ig, strongly supports the concept of heterogeneity of suppressor cell systems (26). Additional evidence supporting this concept in vivo comes from the observations in mice $(27,28)$. Ramshaw et al. (27) demonstrated that the $\mathrm{T}$ lymphocytes that suppress humoral and cell-mediated immunity in $\mathrm{CBA} / \mathrm{H}$ mice differ in the cell surface structure they express. The suppressor $\mathrm{T}$ cells of delayed-type hypersensitivity are $\mathrm{Ly}-\mathrm{I}+$, Ly-2-, and Ia-, whereas the suppressor $\mathrm{T}$ cells of antibody formation are Ly-1-, Ly-2+, and Ia +. Whisler and Stobo (28) similarly demonstrated that the suppressor cells that inhibited the humoral response to sheep erythrocytes were quite distinct with regard to their density from those suppressors that inhibited delayed-type hypersensitivity to sheep erythrocytes.

The present studies demonstrate the need to use different in vitro assay systems when characterizing suppressor cell activity in disease states. Furthermore, knowledge of the steroid sensitivities (and perhaps of other immuno-suppressive agents) with regard to the various $T$-cell suppressive systems will help in the therapy of immunologically mediated disease states.

\section{ACKNOWLEDGMENTS}

We thank Heide Cannon and Janet Gorman for their technical assistance, and Deborah Bush and Avis Brent for their excellent secretarial help.

This work was supported in part by the Biomedical Research Support grant to the University of Virginia School of Medicine by the National Institute of Health, grant 5507 RRO 5431-15, and by the Charlottesville Renal Development Fund.

\section{REFERENCES}

1. Katz, D. H., and B. Benacerraf. 1972. The regulatory influence of activated $T$ cells on $B$ cell responses to antigen. Adv. Immunol. 15: 1-96.

2. Gershon, R. K. 1974. T cell control of antibody production. Contemp. Top. Mol. Immunol. 3: 1-40.

3. Dutton, R. W. 1973. Inhibitory and stimulatory effects of concanavalin A on the response of mouse spleen cell suspensions to antigen. Evidence for separate stimulatory and inhibitory cells. J. Exp. Med. 138: 1496-1505.

4. Feldman, M., P. C. L. Beverly, and M. Dunkley. 1975. 
Different Ly antigen phenotypes of in vitro induced helper and suppressor cells. Nature (Lond.). 258: 614616.

5. Broder, S., D. Poplack, J. Whang-Peng, M. Durm, C. Goldman, L. Muul, and T. Waldmann. 1978. Characterization of a suppressor-cell leukemia. N. Engl. J. Med. 298: 66-72.

6. Feldman, M., P. C. L. Beverly, J. Woody, and I. F. C. McKenzie. 1977. T-T interactions in the induction of suppressor and helper T cells. Analysis of membrane phenotype of precursor and amplified cells. J. Exp. Med. 145: 793-801.

7. Haynes, B. F., and A. S. Fauci. 1978. Heterogeneity of concanavalin A generated suppressor cells of pokeweed mitogen induced plaque forming cell response of human peripheral blood lymphocytes.J. Immunol. 121: 559-565.

8. Dutton, R. W. 1972. Inhibitory and stimulatory effects of concanavalin A on the response of mouse spleen suspensions to antigen. Characterization of the inhibitory cell activity. J. Exp. Med. 136: 1445-1460.

9. Rich, R. R., and C. W. Pierce. 1973. Biological expressions of lymphocyte activation. Generation of a population of thymus derived suppressor lymphocytes. J. Exp. Med. 137: 649-659.

10. Shou, L. S., A. Schwartz, and R. A. Good. 1976. Suppressor cell activity after concanavalin A treatment of lymphocytes from normal donors. J. Exp. Med. 143: 1100-1110.

11. Haynes, B. F., and A. S. Fauci. 1977. Activation of human B lymphocytes. concanavalin A induced generation of suppressor cells of the plaque forming cell response of normal human B lymphocytes. J. Immunol. 118: 22812287.

12. Siegal, F. P., M. Siegal, and R. A. Good. 1976. Suppression of B cell differentiation by leukocytes from hypogammaglobulinemic patients. J. Clin. Invest. 58: 109-122.

13. Segall, M., M. D. Widmer, D. J. Schendel, B. J. Atler, F. H. Bach, and M. L. Bach. 1976. Mixed leukocyte culture and cell-mediated lympholysis techniques. In $\mathrm{Na}$ tional Institute of Allergy and Infectious Disease (NIAID) Manual of Tissue Typing Techniques. J. G. Ray, D. B. Hare, P. D. Pedersen, and D. I. Mullally, editors. 133135.

14. Lobo, P. I., and D. A. Horwitz. 1976. An appraisal of Fc receptors on human peripheral blood B and L lymphocytes. J. Immunol. 117: 939-943.

15. Kurnick, J. T., C. Bell, and H. M. Grey. 1976. PHA induced activation of suppressor cells in normal human peripheral blood lymphocytes. Scand. J. Immunol. 5: 771-778.

16. Hunninglake, G. W., and A. S. Fauci. 1977. Lymphocyte mediated cytotoxicity against human allogeneic and autologous lymphoid targets after concanavalin A activation of cytotoxic effector cells. J. Immunol. 119: 1122-1128.

17. Siegal, F. P., and M. Siegal. 1977. Enhancement by irradiated $\mathrm{T}$ cells of human plasma cell production: dissection of helper and suppressor functions in vitro. J. Immunol. 118: 642-647.

18. Waldmann, T. A., S. Broder, R. Krakauer, R. P. MacDermott, M. Durm, C. Goldman, and B. Meade. 1976. The role of suppressor cells in the pathogenesis of common variable hypergammaglobulinemia and the immunodeficiency associated with myeloma. Fed. Proc. 35: 20672072.

19. Dutton, R. W. 1975. Suppressor T cells. Transplant. Rev. 26: 39-55.

20. Pierce, C. W., D. L. Peavy, and T. Tadakuma. 1975. Suppressor $\mathrm{T}$ cells as regulators of lymphocytes functions. Ann. N. Y. Acad. Sci. 256: 365-374.

21. Haynes, B. F., and A. S. Fauci. 1978. Activation of human B lymphocytes. Kinetics and mechanisms of suppression of plaque forming cell responses by concanavalin A generate suppressor cells. J. Immunol. 120: 700-708.

22. Haynes, B. F., and A. S. Fauci. 1978. Heterogeneity of concanavalin A generated suppressor cells of the pokeweed mitogen induced plaque forming cell response of human peripheral blood lymphocytes. J. Immunol. 121: 559-565.

23. Sakane, T., and I. Green. 1977. Human suppressor T cells induced by concanavalin A. Suppressor T cells belong to distinctive T cell subclasses.J. Immunol. 119: 1169-1178.

24. Tada, T., T. Takemori, K. Okumara, M. Nonaka, and T. Tokuhisa. 1978. Two distinct types of helper $T$ cells involved in the secondary antibody response: independent and synergistic effects of the $\mathrm{Ia}-$ and $\mathrm{Ia}+$ helper $\mathrm{T}$ cells. J. Exp. Med. 147: 446-458.

25. Waldman, H. 1977. Conditions determining the generation and expression of T helper cells. Immunol. Rev. 35: $121-145$.

26. Stobo, J. D., S. Paul, P. E. VanScoy, and P. E. Hermans. 1976. Suppressor thymus-derived lymphocyte in fungal infections. J. Clin. Invest. 57: 319-328.

27. Ramshaw, I. A., I. F. C. McKenzie, P. A. Bretscher, and C. R. Parish. 1977. Discrimination of suppressor T cells of humoral and cell mediated immunity by anti-Ly and anti-Ia sera. Cell Immunol. 31: 364-369.

28. Whisler, R. L., and J. D. Stobo. 1978. Suppression of humoral and delayed hypersensitivity responses by distinct $\mathrm{T}$ cell subpopulations. J. Immunol. 121: 539-542. 